\title{
International Epidemiology of Mollusc Diseases: Learning the Lessons from Two Recent Assessments on Susceptible and Vector Species by the European Food Safety Authority
}

\author{
Franck C. J. Berthe* and Ana Afonso \\ Animal Health and Welfare (AHAW) Panel, European Food Safety Authority (EFSA), \\ Largo N. Palli 5/A, 43100 Parma, Italy
}

\begin{abstract}
Describing diseases in populations is the literal aim of epidemiology. From that point of view, molluscs and mollusc diseases put epidemiologists and other related "ogists" under serious challenges. Two recent assessments conducted by the Animal Health and Welfare (AHAW) Panel of the European Food Safety Authority (EFSA) have highlighted some of these challenges. In an attempt to establish a list of species susceptible to certain diseases, a set of objective criteria pertaining to pathogen replication, viability, host response and pathology, were established. Screening the peer-reviewed literature to document these criteria revealed that studies on diseases of molluscs and techniques applied to case investigation usually provide a great deal of information. However, thorough identification of the pathogen is frequently lacking. In addition, application of the criteria has led to unexpected outcomes of the assessment when species usually regarded as susceptible do not fulfil the criteria. If not susceptibility, the presence of a pathogen in a host leaves very little space for interpretation. From the viewpoint of transfer of pathogens, susceptible species and biological vectors may present equivalent risks. The concept of vector has itself proved to be a subject for controversy and definitions in the international standards for health management have shown to be potentially misleading in assessing the risk of transferring pathogens via transfers of live animals. A second assessment of the AHAW panel to list potential vector species highlighted a range of situations from mechanical carriage to actual infection. Interestingly, some of the conclusions of this risk assessment were later comforted by experimental data. Both the lack of accurate identification of mollusc pathogens and inconsistency in host species categorization result in poor understanding of epidemiology of diseases in molluscs. These issues are illustrated by selected examples.
\end{abstract}

Key words: mollusc, epidemiology, diagnostic, infection, disease, susceptibility, definition, risk assessment

In the mid-2000s, the world aquaculture production of molluscs was close to the third of the total world production of aquatic products in volume. A relatively low number of species contribute to the bulk of this production; the Pacific cupped oyster Crassostrea gigas having the greatest contribution by far (FAO, 2007).

Success stories, including the soaring of abalone industry or pearl farming, are among the drivers of general interest for mollusc aquaculture. As a result, there have been many transfers of stocks and introductions of non-native mollusc species in support to farming activities. Such introductions have been shown in the past to be a major cause for pathogen transfers and disease spreading (Corbeil and Berthe, 2009). Over the last 50 years, on average, five aquatic animal species

\footnotetext{
* Corresponding author

E-mail: Franck.BERTHE@efsa.europa.eu

This paper was presented in " 5 th International Symposium of the Japanese Society for Fish Pathology" held in Tokyo (October 18-19, 2008).
}

were added per year to aquaculture systems. According to FAO, the most rapid growth in terms of number of species added per year occurred between 1980 and 1990 with nearly 10 species per year; a figure that should be compared to only 0.3 species added from 1950 to 1960 (FAO, 2007). The susceptibility of these new species to known and unknown pathogens remains for investigation. The associated risk in terms of new, emerging and re-emerging diseases should be assessed.

Based on the Greek etymology of the term, epidemiology is the knowledge of diseases in a population. As such, epidemiology is key to success for disease control and health management programs. Accurate description, knowledge and understanding of pathogen distribution in their respective host species is a common goal of risk managers. In a global context of increasing aquaculture production and international trade of aquatic products, molluscs and mollusc diseases put the epidemiologist and other related "ogists" under serious challenges. 
Two recent assessments conducted by the Animal Health and Welfare (AHAW) panel of the European Food Safety Authority (EFSA) have highlighted some of these challenges. The first assessment specifically dealt with the possible role of aquatic species as vectors of mollusc diseases (EFSA, 2007). The second one aimed at establishing a list of mollusc species susceptible to certain diseases (EFSA, 2008). Both issues, susceptibility and possible role as vectors, are obvious tributaries of the central issue of pathogen transmission and spread. Beyond the apparent simplicity of the two questions however, our investigations have revealed the actual complexity of mollusc epidemiology and surfaced inconspicuous underlying issues.

In an attempt to illustrate those issues, this paper relates our assessment and associated reflexions.

\section{Susceptible and Vector Species}

Since August 2008, the member states of the European Union have implemented Council Directive 2006/88/EC that establishes minimum measures for the control of aquatic animal diseases. This new Directive is the current legislative framework in Europe on animal health requirements for aquaculture animals and products, and for the prevention and control of certain infectious diseases in aquatic animals. As such it is also a reference for risk assessments performed by the Animal Health and Welfare (AHAW) panel of the European Food Safety Authority (EFSA) when it deals with aquatic animal health issues.

Directive 2006/88/EC provides definitions for several terms, including "susceptible species" and "vectors". According to these definitions, any species in which infection by a disease agent has been demonstrated by natural cases or by experimental infection that mimics the natural pathways is susceptible. A vector species is a species that is not susceptible to a disease but which is capable of spreading infection by conveying pathogens from one host to another. These definitions are contextual and substantially differ from those commonly used in biology (EFSA, 2007). The direct application of these definitions to retrieve and evaluate information from the scientific literature may therefore prove to be difficult. For example, the natural pathways referred to in the definition for susceptible species are largely unknown for most of mollusc diseases under consideration.

Marteilia refringens and $M$. sydneyi provide an interesting illustration from this point of view. While $M$. refringens is believed to have a luminal route to its target organ (digestive gland), M. sydneyi was shown to progress through the connective tissue of its host (reviewed by Berthe et al., 2004). Not only very little is known on natural routes of infection, but extrapolation even for closely related pathogens should be regarded as hazardous.

Many published studies are designed to experimentally investigate the susceptibility of a new host species. The question of natural pathways is particularly critical when interpreting such experimental data. For instance, experimental demonstration brought by injection is a rather invasive means in an attempt to fulfil first Koch's postulates; and quite unlikely to mimic the natural pathways of infection. For the purpose of our assessment, we consequently decided to characterise experimental data as "invasive" or "non invasive". Where cohabitation and bathing are obvious non invasive procedures, injection or oral dosing (e.g. forced feeding) were regarded as invasive.

Oral dosing bypasses the gills and labial palps filtering system that plays a major role in particle sorting and rules access to the digestive tract. It has been used, for example, in experimental transmission of Bonamia ostreae by inoculation of purified parasites in its natural host (Hervio et al., 1995) and other host species (Renault et al., 1995). Those experiments exclude filtering function from their design and therefore significantly diverge from natural pathways: they are invasive.

Invasive experimental infection, although not mimicking the natural pathways of infection, still give important information on pathogenesis of a particular agent. Clearly, information obtained from invasive experimental data may provide an indication of a potential susceptibility; this is important to record since such information calls for subsequent research.

Because of the recognised difficulty in directly applying contextual definitions, it was proposed to develop and use a set of objective criteria reflecting cardinal points of reference. For susceptibility, the working criteria are related to pathogen replication (does the pathogen replicate or multiply in the host tissues?), viability (is the pathogen viable in this host species?), host response and pathology (does host tissues show response to the presence of the pathogen?), and location (is the pathogen observed in an expected target tissue or organ?). The scientific data provided by the peer-reviewed literature were therefore to be scrutinised for relevance with: a) thorough identification and characterisation of the pathogen which is an obvious prerequisite, b) natural pathways or experimental design reflecting the natural pathways of infection, and c) support to the four criteria. Essentially, susceptibility to infection is assessed based on a combination of these criteria. While viability of the pathogen by itself would not be sufficient, evidence for pathogen replication makes a good case for susceptibility.

By and large, studies on diseases of molluscs and techniques applied to case investigation usually provide a great deal of information related to those criteria. Eventually, the assessment led to two groups of species: a first group contained those host species for 
which the quality of the data provided clear support for susceptibility, while a second group contained a number of potential host species that were disqualified based on the uncertainty of the required information (e.g. incomplete or unclear data prevented a clear conclusion or the only available data was obtained from invasive experiments).

Tissue location is frequently well documented for molluscs because histopathology remains a commonly used technique in the investigation of mollusc diseases. Paradox is that where being restricted to histology is usually seen as a limitation in mollusc health sciences (Miahle et al., 1995; Berthe et al., 1999), in our assessment histology provided a significant corpus of information (EFSA, 2008). As a matter of fact, assessment of susceptibility of Crassostrea ariakensis for Bonamia ostreae and Ostrea angasi for $B$. exitiosa was based on tissue location, host response and pathology (Cochennec et al., 1998; Heasman et al., 2004; EFSA, 2008).

The caveat is that, despite the great number of histological studies, pathology is still poorly addressed in the peer reviewed literature. The comprehensive review of the published literature performed by EFSA (2008) showed that too many authors and investigators are not pathologists but rather carry out histological bug hunting. Bug hunters are a real limitation to our capacity to reply to relevant criteria. Efforts should be made by the community to maintain and reinforce its strong capacity in histology and pathology of molluscs.

Demonstrating pathogen viability in the case of mollusc pathogens appears to be a real challenge in a first approach as very few of the pathogens under consideration may be cultured. Culture systems have been developed for Perkinsus species (reviewed by Villalba et al., 2004). Attempts have been made for Bonamia and Marteilia; but without success beyond maintaining some parasitic cells alive in artificial medium for few days. Several elements may however come to support viability criterion: cohabitation with specific pathogen free susceptible animals (B. ostreae), presence of spores in the faeces ( $M$. refringens) could be used to support criterion for viability (EFSA, 2008). The criterion of viability of the pathogen thus required a bit of data mining and intelligent reading, leaving a lot of room for interpretation and subjective analysis.

Pathogen replication has shown to be sometimes difficult to interpret. Again this requests a case by case approach and how to interpret this criterion mainly depends on the pathogen considered. For example, we used observation of bi-nucleated plasmodia of Bonamia ostreae in transmission electron microscopy as a way to support replication. In the case of Marteilia refringens, the presence of different developmental stages of the parasite, including tertiary cells, was believed to support the criterion. In fact, this is greatly matter of interpretation: $M$. refringens has been reported from Crassostrea gigas (Cahour, 1979; Riera et al., 1993; Montes et al., 1998). These authors have reported early stages of development in the epithelium of the oesophagus and stomach of infected oysters, limited to primary and secondary cells. If one accepts the theory of Perkins that Marteilia stem cells are amoeboid cells (Berthe et al., 2004), then, strictly speaking, secondary cells should be regarded as a positive sign of parasite development. Subsequently, C. gigas would become automatically susceptible to the disease, although it is commonly accepted that the parasite development cycle aborts in this particular host species.

In summary, literature provided support to the four criteria identified to assess host susceptibility. However, we should make two comments here:

First is that published papers suggesting a demonstrated susceptibility do rarely properly and rigorously approach this issue. In many instances during our assessment, data pertaining to replication or growth of the pathogen, its viability, associated histopathology, and tissue location were to be extracted from peer reviewed papers that were published initially for a different purpose. The use of a set of objective criteria to demonstrate susceptibility should be more broadly encouraged in the scientific community and through the peer reviewing process.

Secondly, there is still a significant field of basic biology knowledge on listed pathogens that has not been explored and successfully investigated. These data-gaps do hamper our capacity to assess susceptibility; furthermore, they impede our capacity in decision making. These should be identified as priority for research.

However, thorough identification of the pathogen is by far the most frequent missing information to reach any conclusion. Despite tremendous improvements since the mid-1990s in taxonomy of mollusc pathogens, and diagnostic capacity, there are still many reports of occurrence that cannot be interpreted and assessed beyond the genus level. For example, there are scientific data suggesting infection with Marteilia refringens in Ostrea denselamellosa, O. angasi, O. puelchana, O. chilensis, Crassostrea gigas, C. virginica, Cardium edule, Ruditapes decussatus, R. philippinarum, Tapes rhomboides, T. pullastra, Ensis minor, Scrobicularia piperata, Saccostrea cucullata with however uncertainty on parasite identification (EFSA, 2007, 2008). This leads to a great uncertainty in terms of biological reservoirs of the parasite.

In another example, SSU rDNA gene sequence data suggest that Mikrocytos roughleyi, Bonamia exitiosa and several American isolates of Bonamia may be con-specific (reviewed by Carnegie and CochennecLaureau, 2004). In our assessment, the application of a broad definition of $B$. exitiosa has a direct impact on its host and geographic range. It would add three 
more species to the list of susceptible hosts, including non-Ostrea species. However, uncertainty on parasite identification and taxonomic affiliation hampers full scientific support. The paradox here is that although considerable amounts of molecular information data are available the scientific community could not yet reach a pragmatic agreement on taxonomy of microcells.

Clear definitions of pathogens and how differentiation of strains is possible are fundamental to assessment of susceptibility of host species. Any change in these definitions has an impact on the host and geographic ranges of listed diseases.

From the viewpoint of transfer of pathogens, susceptible species and biological vectors may present equivalent risks. The concept and definitions of vector in the aquatic standards for health management have however proved to be a subject for discussion within scientific panels. This, beyond conversation in biology and academic debates, can be potentially misleading in assessing the risk of transferring pathogens via transfers of live animals and products. In attempting to establish a list of potential vector species, a range of situations from pure mechanical carriage to actual infection was highlighted (EFSA, 2007).

For example, cupped oysters (Crassostrea, Saccostrea spp.) have been identified as potential vectors for Bonamia exitiosa with a moderate likelihood (EFSA, 2007); this was somehow later confirmed by the fact that $S$. glomerata is considered as a susceptible species (EFSA, 2008) and C. ariakensis could also possibly be recognised as susceptible. Similarly, the vector assessment identified clams and cockles as a group of mollusc species being potential vectors for Marteilia refringens with a moderate likelihood (EFSA, 2007). The susceptibility assessment tends to show that indeed several species of molluscs (not only clams and cockles but also cupped oysters) would be susceptible to infection with $M$. refringens. Where to draw the line?

During the vector assessment (EFSA, 2007), it became more and more obvious that indeed conditions leading to the possible carriage of pathogens was becoming central. Interestingly, some of the conclusions of the vector assessment were later confirmed by experimental data. For example, Lynch et al. (2007) have investigated the presence of Bonamia ostreae DNA using polymerase chain reaction (PCR) in benthic macro invertebrates and zooplankton. $B$. ostreae was detected by the authors in eight benthic macro-invertebrates and 19 grouped zooplankton samples. Among them, Actina equine (Anthozoa) and Ascidiella aspersa (Ascidiacea) were found attached to Ostrea edulis shells. No in situ hybridisations (ISH) and histological examinations come to confirm and localise the parasite in the host tissues. However, transmission of $B$. ostreae was effective to two naïve oysters by cohabiting with the brittle star Ophiothrix fragilis (Lynch et al.,
2007). Those species of invertebrates and zooplankton do not qualify against the definition for vector or susceptible species as laid down by Directive 2006/88/EC (they are not farmed). However, the EFSA scientific opinion on vector species has highlighted the potential for commercial bivalve species to act as mechanical vectors (i.e. vessels or vehicles) because of fouling and aggregates on the shells (EFSA, 2007).

In another example, a moderate likelihood to act as vectors for Bonamia ostreae has identified for clams, cockles and scallops (EFSA, 2007). Recent data suggest that $B$. ostreae may be detected by PCR from various mollusc species including scallops (Haliotis tuberculata, Crassostrea gigas and Pecten maximus) which are not considered to be susceptible (S. Culloty, pers. com.).

Excessively framing definitions can pose difficulties. Technically, copepods cannot be qualified as vectors or susceptible species with regards to Directive working definitions given that these species are neither farmed nor traded. However, Audemard et al. (2002) have identified Paracartia grani as an intermediate host in the life cycle of Marteilia refringens and intermediate hosts do propagate infection. More recently, new intermediate host candidate species were identified on the basis of PCR positive results (Carrasco et al., 2007). In the case of $P$. grani, this species would clearly be recognised as susceptible according the criteria used in EFSA 2008.

Our assessments have highlighted different levels of risk (EFSA, 2007, 2008) and this need to be addressed. The main lesson one should take from these two assessments is clearly that to be or not to be susceptible (or vector) is not the question. The right question is clearly about risk of transferring pathogens and infectious diseases.

The lack of clear case definition for the listed pathogens is one of the main limitations to the assessment of host species susceptibility. Both the lack of accurate identification of mollusc pathogens and inconsistency in host species categorization contribute to the poor understanding of mollusc diseases epidemiology.

To conclude, against most commonly accepted truism, methods applicable to mollusc diseases are not a limiting factor to describing their epidemiology. The descriptive epidemiology of mollusc diseases is hampered by fundamental but inconspicuous questions of taxonomy and basic biology. There is an urgent need for the scientific community to address those questions.

\section{Acknowledgements}

The authors acknowledge the members of the European Food Safety Authority (EFSA) Working Groups for Vector Species and Susceptible Species for valuable discussion during the preparation of data 
included in this review and particularly the respective chairs of those groups, Drs. Ron Roberts and Mike Sharp. F. Berthe acknowledges the invitation made by the Japanese Society of Fish Pathology for completion of this review.

\section{References}

Audemard, C., F. Le Roux, A. Barnaud, C. Collins, B. Sautour, P. G. Sauriau, X. de Montaudouin, C. Coustau, C. Combes and F. Berthe (2002): Needle in a haystack: involvement of the copepod Paracartia grani in the life-cycle of the oyster pathogen Marteilia refringens. Parasitology, 124, 315323.

Berthe, F. C. J., E. M. Burreson and M. Hine (1999): Use of molecular tools for mollusc disease diagnosis. Bull. Eur. Ass. Fish Pathol., 19, 277-278.

Berthe, F. C. J., F. Le Roux, R. D. Adlard and A. Figueras (2004): Marteiliosis in molluscs: A review. Aquat. Living Resources, 17, 433-448.

Cahour, A. (1979): Marteilia refringens and Crassostrea gigas. In "Haplosporidian and haplosporidian-like diseases of shellfish". An international symposium held at the Virginia Institute of Marine Science, Gloucester Point, VA, 17-19 August 1977. Mar. Fish. Rev., 41, 19-20.

Carnegie, R. and N. Cochennec-Laureau (2004): Microcell parasites of oysters: Recent insights and future trends. Aquat. Living Resources, 17, 519-528.

Carrasco, N., I. López-Flores, M. Alcaraz, M. D. Furones, F. C. J. Berthe and I. Arzul (2007): First record of a Marteilia parasite (Paramyxea) in zooplankton populations from a natural estuarine environment. Aquaculture, 269, 63-70.

Cochennec, N., T. Renault, P. Boudry, B. Chollet and A. Gérard (1998): Bonamia-like parasite found in the Suminoe oyster Crassostrea rivularis reared in France. Dis. Aquat. Org., 34, 193-197.

Corbeil, S. and F. C. J. Berthe (2009): Disease and molluscs quality. In "Shellfish safety and quality" (ed. by S. E. Shumway and G. E. Rodrick). Woodhead Publishing, USA, $608 \mathrm{p}$.

EFSA (2007): Scientific opinion of the panel on Animal Health and Welfare on a request from the European Commission on possible vector species and live stages of susceptible species not transmitting disease as regards certain mollusc diseases. EFSA J., 597, 1-116.
EFSA (2008): Scientific opinion of the panel on Animal Health and Welfare on a request from the European Commission on aquatic animal species susceptible to diseases listed in the Council Directive 2006/88/EC. EFSA J., 808, 1-145.

FAO (2007): The state of world fisheries and aquaculture 2006. Available from: http://www.fao.org/docrep/009/A0699e/ A0699e00.htm.

Heasman, M., B. K. Diggles, D. Hurwood, P. Mather, I. Pirozzi and S. Dworjanyn (2004): Paving the way for continued rapid development of the flat oyster (Ostrea angasi) farming industry in New South Wales. Final Report to the Department of Transport \& Regional Services, Project No. NT002/0195. NSW Fisheries Final Report No. 66. ISSN 1442-0147. $40 \mathrm{p}$

Hervio, D., E. Bachère, V. Boulo, N. Cochennec, V. Vuillemin, Y. Le Coguic, G. Cailletaux, J. Mazurié and E. Miahle (1995): Establishment of an experimental infection protocol for the flat oyster, Ostrea edulis, with the intrahaemocytic protozoan parasite, Bonamia ostreae: application in the selection of parasite-resistant oysters. Aquaculture, 132, 183-194.

Lynch, S. A., D. V. Armitage, J. Coughlan, M. F. Mulcahy and S. C. Culloty (2007): Investigating the possible role of benthic macroinvertebrates and zooplankton in the life cycle of the haplosporidian Bonamia ostreae. Exp. Parasitol., 115, 359-368.

Mialhe, E., E. Bachère, V. Boulo, J. P. Cadoret, J. Saraiva, L. Carrera, C. Rousseau, V. Cedeno, J. Calderon, R. R. Colwell (1995): Future of biotechnology-based control of disease in marine invertebrates. Mol. Mar. Biol. Biotechnol., 4, 275-283.

Montes, J., M. A. Longa, A. Lama and A. Guerra (1998): Marteiliosis of Japanese oyster (Crassostrea gigas) reared in Galicia NW Spain. Bull. Eur. Ass. Fish Pathol., 18, 124126.

Renault, T., N. Cochennec and H. Grizel (1995): Bonamia ostreae, parasite of the European flat oyster, Ostrea edulis, does not experimentally infect the Japanese oyster, Crassostrea gigas. Bull. Eur. Ass. Fish Pathol., 15, 78-80.

Riera, V., M. Santmarti and M. Durfort (1993): Presencia de Marteilia refringens en los cultivos de moluscos bivalvos del litoral Catalan. Actas IV Congreso Nac. Acuicult. pp. $539-544$.

Villalba, A., K. S. Reece, M. Camino Ordas, S. M. Casa and A. Figueras (2004): Perkinsosis in molluscs: a review. Aquat. Living Resources., 17, 411-432. 